\title{
Daya Predasi dan Tanggap Fungsional Kumbang Unta (Ophionea nigrofasciata) pada Beberapa Kepadatan Wereng Batang Coklat (Nilaparvata lugens)
}

\section{Predation Rate and Functional Response of Camel Groundbeetle (Ophionea nigrofasciata) on Several Densities of Brown Planthopper (Nilaparvata lugens)}

Tre Julia Nasral ${ }^{1)}$, My Syahrawati ${ }^{2)^{*}}$, Yenny Liswarni ${ }^{2)}$

1) Program Studi Agroteknologi Fakultas Pertanian Universitas Andalas

2) Program Studi Proteksi Tanaman Fakultas Pertanian Universitas Andalas

E-mail: mysyahrawati@agr.unand.ac.id

Diterima: 26 Maret 2020 Disetujui: 08 Juni 2020 Dipublikasi: 30 Juni 2020

\begin{abstract}
Camel groundbeetle (Ophionea nigrofasciata Schmidt-Goble 1846) or CGB is reported as one of predators of brown planthopper (Nilaparvata lugens Stal 1854) or BPH. The difference in BPH densities is assumed to affect the predation rate of the CGB. This study aimed to determine the predation rate of CGB on BPH at different densities. This experiment used a completely randomized design (CRD) consisting of six treatments and five replications. The treatment consisted of predation of one CGB at several BPH densities $(5,10,20,30,40$, and 50 individuals). BPH used was second-third instar of nymphs, and the CGB used was female. The results showed that the predation rate of CGB increased with increasing BPH density with functional response types classified as type I (Linear). The highest predation occurred at 50 density (23.6 individuals or $47.2 \%$ of BPH provided). The difference in density of $\mathrm{BPH}$ did not affect the bodyweight gain of CGB and tended to decrease due to different prey-seeking behavior.
\end{abstract}

Keywords: Nillaparvata lugens, Ophionea nigrofasciata, predation, predator

\section{PENDAHULUAN}

Serangan wereng batang coklat (WBC) pada tanaman padi di Indonesia pertama kali dilaporkan pada tahun 1939 di Dramaga Bogor, diikuti serangan di Yogyakarta dan Mojokerto pada tahun 1940. Serangan WBC di Sumatera Barat mulai mengemuka sejak tahun 2009, diikuti dengan ledakan populasi sejak tahun 2015. Luas serangan pada tahun 2015 mencapai 550,71 ha, pada tahun berikutnya meningkat menjadi 865,93 ha, pada tahun 2017 meningkat lagi menjadi 751,51 ha dan menurun pada tahun 2018 menjadi 399,85 ha (BPTPH Sumatera Barat, 2019). Persentase serangan WBC di daerah endemik Kota Padang berkisar 51,6-94,1\% sedangkan intensitas serangan hama ini diklasifikasikan rendah dengan nilai berkisar 6,01-10,55\% (Syahrawati et al., 2019).

Salah satu teknik pengendalian WBC yang diunggulkan adalah penggunaan musuh alami. Pengendalian menggunakan musuh alami tidak menyebabkan pencemaran lingkungan dan tidak mengganggu atau merusak keragaman hayati. Beberapa musuh alami yang dapat mengendalikan WBC dari kelompok predator adalah 
Pardosa pseudoannulata, Tetragnatha sp., Oxyopes javanus, Callitrichia spp., Paederus fuscipes, Coccinella spp., Microvelia atrolineata dan Ophionea nigrofasciata (Kartohadjono, 2011; Tauruslina et al., 2015).

Ophionea nigrofasciata SchmidtGoble 1846 (Coleoptera: Carabidae) atau kumbang unta termasuk serangga predator yang sering ditemukan di areal persawahan, terutama pada rongga lipatan daun padi yang dibuat oleh larva penggulung daun (Cnaphalocrosis medinalis Guenee) (Shepard et al., 1987). Populasinya dilahan pertanian tergolong rendah. Menurut Putranto (2016), kumbang unta mulai muncul di sawah pada 2 minggu setelah tanam (MST) dengan rata-rata populasi sebanyak 0,01 individu per rumpun. Sebaliknya Defaosandi (2010) dan Najah (2018) melaporkan bahwa kumbang unta ditemukan di persawahan pada 9-15 MST tapi tidak ditemukan pada 3-5 MST. Populasi kumbang unta pada 9 MST yakni 0,9 per rumpun dan pada 15 MST menurun menjadi 0,1 per rumpun. Secara spesifik, Najah (2018) melaporkan adanya fluktuasi populasi kumbang unta di lahan sawah pada tanaman padi, ditemukan sebanyak 0,03 individu kumbang unta per rumpun pada 5 MST, sebanyak 0,36 individu per rumpun pada 8 MST, dan tidak ditemukan pada $12 \mathrm{MST}$.

Informasi tentang daya predasi kumbang unta pada WBC masih sedikit sekali. Shepard et al. (1987) melaporkan bahwa kumbang unta dapat memangsa 35 nimfa WBC per hari. Dari hasil penelitian Karindah (2011) diketahui bahwa kumbang unta dapat memangsa 4-5 nimfa WBC instar 4-5 ketika disediakan 20 nimfa WBC. Kedua penelitian tersebut tidak memperhitungkan pengaruh perbedaan kepadatan mangsa terhadap daya predasi. Berbagai hasil penelitian sebelumnya menunjukkan adanya pengaruh kepadatan terhadap daya predasi suatu predator.
Syahrawati (2015) melaporkan bahwa kepadatan WBC berpengaruh terhadap daya predasi Pardosa pseudoanulata. Kemampuan memangsa $P$. pseudoanulata mengalami peningkatan seiring dengan bertambahnya kepadatan mangsa, berturut-turut 3,1, 7,9, 12,9 dan 15,2 ekor per harinya pada kepadatan 5, 10, 15 dan 20 ekor WBC. Selanjutnya kemampuan memangsa Menochilus sexmaculatus terhadap Aphis gossypii pada kepadatan 10, 20, 30, 40 dan 50 ekor juga meningkat seiring dengan meningkatnya kepadatan yakni, 10, 20, 29.75, 38, 44.5 ekor (Nelly et al., 2012). Hermanda (2019) juga melaporkan bahwa kemampuan memangsa Phidippus sp. terhadap $N$. lugens pada kepadatan 10, 20, 30, 40, dan 50 ekor meningkat seiring dengan meningkatnya kepadatan yakni 9, 13,4, 23,6, 26,4, dan 28,2 ekor.

Daya predasi pada kepadatan mangsa yang berbeda berkaitan dengan tanggap fungsional predator. Tanggap fungsional merupakan salah satu indikator untuk menentukan ukuran keefektifan suatu predator dalam metode pengendalian hayati (Rogers, 1972; Hassel, 2000). Selanjutnya Nelly et al. (2005) menyatakan bahwa tanggap fungsional merupakan komponen yang sangat esensial dalam hubungan predator dan mangsanya, karena dapat memberikan gambaran bagaimana potensi suatu predator dalam mengendalikan suatu populasi mangsanya. Tanggap fungsional diperkenalkan oleh Holling dengan memperkenalkan tiga tipe tanggap fungsional yakni tipe I (linear), tipe II (Eksponensial/Hiperbolik) dan tipe III (Logaritmik/sigmoidal) (Holling, 1959; Denny, 2014). Penelitian ini bertujuan untuk mengetahui daya predasi dan tanggap fungsional dari kumbang unta terhadap wereng batang coklat pada kepadatan yang berbeda. 


\section{METODOLOGI}

Penelitian ini telah dilaksanakan di Laboratorium Bioekologi Serangga Jurusan Hama dan Penyakit Tanaman Fakultas Pertanian Universitas Andalas Padang dari bulan Juni sampai Agustus 2019. Selama pengamatan berlangsung, suhu dan kelembaban relatif harian diukur menggunakan termohydrometer. Adapun rata-rata suhu minimum harian adalah $27.6^{\circ} \mathrm{C}$ dan suhu maksimum harian $28.4^{\circ} \mathrm{C}$, sedangkan untuk kelembaban relatif minimum harian adalah $72.1 \%$ dan rata-rata maksimum harian adalah $76.1 \%$.

\section{Metode}

Penelitian dilaksanakan menggunakan Rancangan Acak Lengkap (RAL) dengan 6 perlakuan, masing-masing dilaksanakan dalam 5 ulangan. Perlakuan tersebut adalah daya predasi dan tanggap fungsional kumbang unta pada beberapa kepadatan WBC, yaitu: 5, 10, 20, 30, 40 dan 50 ekor.

\section{Perbanyakan WBC uji}

WBC diperoleh dari hasil perbanyakan di laboratorium. Populasi awal WBC dikoleksi dari lahan persawahan di Kecamatan Pauh Kota Padang yang menyerang padi varietas IR 42. Selanjutnya, perbanyakan WBC dilakukan pada benih padi varietas IR 42 sebagai pakan. Benih tersebut direndam selama 24 jam untuk merangsang kecambah akar, kemudian dikering-anginkan selama lebih kurang 1 jam, lalu dipindahkan ke dalam stoples

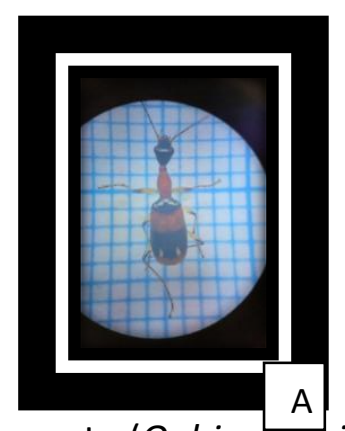

plastik (volume $=25$ liter) yang berisi air setinggi $2 \mathrm{~mm}$. Tinggi air terus dijaga berada pada posisi menutupi benih padi. Setelah bibit padi berumur 5-7 hari, 10 pasang imago WBC dimasukkan ke dalam stoples biakan. Nimfa instar satu akan muncul pada hari ke 7-10 setelah infestasi. Untuk penelitian ini dibutuhkan sebanyak 775 WBC instar 2-3 yang telah diperbanyak dilaboratorium hingga generasi ke 3 .

\section{Penyedian kumbang unta uji}

Imago kumbang unta yang digunakan dalam pengujian adalah populasi lapangan, yang dikoleksi dari lahan persawahan yang ada di Kota Padang. Kumbang unta dikumpulkan menggunakan wadah plastik air mineral volume $240 \mathrm{ml}$ dengan cara mengarahkan mulut wadah plastik air mineral ke kumbang unta dan mendorongnya masuk. Hasil koleksi kemudian dibawa ke laboratorium.

Untuk membedakan imago betina dan imago jantan pertama kali adalah dengan cara menangkap kumbang unta yang sedang kawin beberapa kali, kemudian dilihat perbedaan keduanya melalui warna dan ukuran tubuh. Berdasarkan observasi tersebut diketahui bahwa imago betina memiliki warna tubuh yang lebih gelap, lebar tubuh berkisar antara 2,5-3,0 $\mathrm{mm}$ dengan panjang tubuh 7,5 - 8,0 $\mathrm{mm}$, sedangkan imago jantan memiliki warna tubuh yang lebih terang, lebar tubuh berkisar antara 1,0-1,5 mm dengan panjang tubuh $6,0-7,0 \mathrm{~mm}$ (Gambar 1).

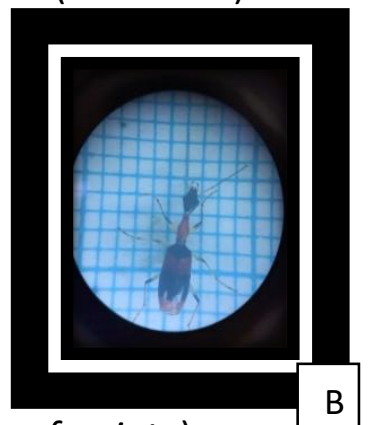

Gambar 1. Imago kumbang unta (Ophionea nigrofasciata) yang urgunakan dalam penelitian: (A) Kumbang unta betina, (B) Kumbang unta jantan (Dokumentasi pribadi). 
Untuk pemeliharaan dan adaptasi, masing-masing kumbang unta betina ditempatkan dalam gelas plastik yang telah diisi bibit padi berumur empat hari setelah semai dan WBC sebanyak 3-5 ekor. Jumlah mangsa akan ditambah setiap kali mangsa yang disediakan habis. Setelah satu minggu, kumbang unta betina dilaparkan selama 6 jam sebelum digunakan dalam pengujian. Dalam penelitian ini dibutuhkan 30 ekor imago kumbang unta betina yang mempunyai ukuran yang yang mendekati sama untuk pengujian.

\section{Penyediaan media uji dan pelaksanaan}

Tiga batang bibit padi berumur empat hari dipindahkan ke dalam gelas plastik (volume $=360 \mathrm{ml}$ ) sebagai wadah uji dan dibutuhkan sebanyak 90 batang bibit padi dan 30 wadah uji untuk semua perlakuan dan ulangan. Kumbang unta dilaparkan pada pagi hari antara pukul 08.00-09.00 sampai pukul 14.00-15.00 wib. Bersamaan dengan waktu pelaparan, wadah uji disiapkan dengan mengisikan tiga batang padi berumur empat hari dan WBC instar 2-3 sesuai perlakuan. Setelah dilaparkan kumbang unta ditimbang berat tubuhnya menggunakan timbangan analitik dengan ketepatan 4 desimal, kemudian dimasukan kedalam wadah uji.

\section{Pengamatan}

\section{Daya Predasi (1×24 jam)}

Pengamatan terhadap jumlah WBC yang dipredasi dilakukan dengan menghitung jumlah nimfa WBC uji yang dimangsa oleh kumbang unta selama $1 \times 24$ jam dari setiap perlakuan. Data tentang jumlah pemangsaan tersebut digunakan untuk mencari persentase pemangsaan. Persentase pemangsaan dihitung menggunakan rumus:

Persentase pemangsaan $=$ $\frac{\text { Jumlah nimfa WBC yang dimangsa }}{\text { jumlah nimfa WBC yang disediakan }} \times 100 \%$

Perkembangan daya predasi (5 hari pengamatan)
Pengamatan terhadap perkembangan daya predasi dilakukan dengan menghitung jumlah nimfa WBC yang dimangsa oleh kumbang unta setiap hari selama 5 hari, kemudian dilihat penambahan pemangsaan setiap harinya.

\section{Perkembangan berat tubuh (g) (5 hari pengamatan)}

Perkembangn berat tubuh kumbang unta diukur setiap hari selama 5 hari dengan membandingkan dengan berat tubuh sebelum perlakuan.

\section{Perilaku pemangsaan}

Pengamatan perilaku memangsa dari kumbang unta dimulai sejak pertama kali dimasukkan ke wadah plastik uji, kemudian diamati selama 1 jam pertama hingga kegiatan mencari, mengejar, menangkap dan membunuh mangsa. Hasil pengamatan dijelaskan secara deskriptif.

\section{Analisis data \\ Daya predasi dan berat tubuh}

Adapun data tentang daya predasi dan berat tubuh predator dianalisis secara statistik sesuai rancangan menggunakan analisis sidik ragam dan dilanjutkan dengan uji Least Significance Different (LSD) taraf 5\% (Software: Statistix 8). Data tentang perkembangan pemangsaan dan berat tubuh ditampilkan dalam bentuk grafik garis.

\section{Tanggap fungsional}

Ada tiga tipe tanggap fungsional menurut Holling (1959) yaitu Tipe I, Tipe II dan Tipe III. Tipe tanggap fungsional ini diperoleh melalui analisis regresi dan korelasi terhadap jumlah WBC yang dipredasi oleh kumbang unta pada berbagai kepadatan yang diuji. Analisis tersebut menggunakan perangkat lunak SPSS 16 . Tipe I ditunjukkan oleh persamaan regresi linear yang berarti bahwa peningkatan laju predasi seiring dengan peningkatan kepadatan mangsa sampai ke titik tertentu, kemudian menjadi konstan karena kekenyangan. Tipe II ditunjukkan oleh persamaan 
Nasral et al. Daya Predasi dan Tanggap Fungsional Kumbang Unta

eksponensial yang berarti peningkatan laju predasi lambat di awal karena adanya waktu belajar, kemudian diikuti oleh peningkatan predasi sampai kenyang. Tipe III ditunjukkan oleh persamaan regresi logaritmik yang berarti terjadi peningkatan predasi di awal dan kemudian melambat. Tipe tanggap fungsional ditentukan melalui nilai $r$ tertinggi yang menunjukkan adanya korelasi erat antara tingkat predasi dan kepadatan mangsa.

\section{HASIL}

\section{Daya predasi (1×24 jam)}

Peningkatan kepadatan WBC cenderung meningkatkan daya predasi oleh kumbang unta selama $1 \times 24$ jam pengamatan, sementara itu tidak ada pengaruh kepadatan WBC terhadap persentase predasi. Daya predasi pada kepadatan 50 ekor lebih tinggi dari pada kepadatan 5-30 ekor, tapi tidak berbeda nyata dengan kepadatan 40 ekor (Tabel 1).

Tabel 1. Rata-rata daya predasi kumbang unta terhadap WBC pada kepadatan berbeda ( $1 \mathrm{x}$ 24 jam)

\begin{tabular}{|c|c|c|}
\hline \multirow{2}{*}{ Kepadatan WBC (Ekor) } & \multicolumn{2}{|c|}{ Daya predasi } \\
\hline & Jumlah individu & Persentase (\%) \\
\hline 5 & $1,6 \quad a$ & $32,0 \quad a$ \\
\hline 10 & $4,6 \quad b$ & $46,0 \quad a$ \\
\hline 20 & $9,4 \quad b$ & $47,0 \quad a$ \\
\hline 30 & $11,8 \quad b$ & $39,3 \quad a$ \\
\hline 40 & $15,2 \mathrm{c}$ & $38,0 \quad a$ \\
\hline 50 & $23,6 \quad c$ & $47,2 \quad a$ \\
\hline
\end{tabular}

Angka yang diikuti oleh huruf kecil yang sama pada baris yang sama, berbeda tidak nyata berdasarkan hasil dari uji LSD pada taraf nyata $5 \%$.

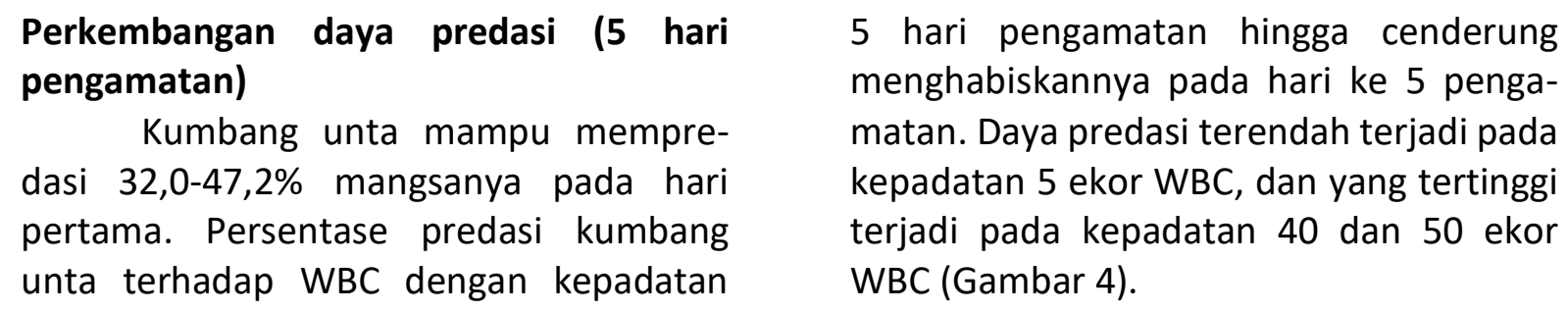
berbeda meningkat setiap harinya selama

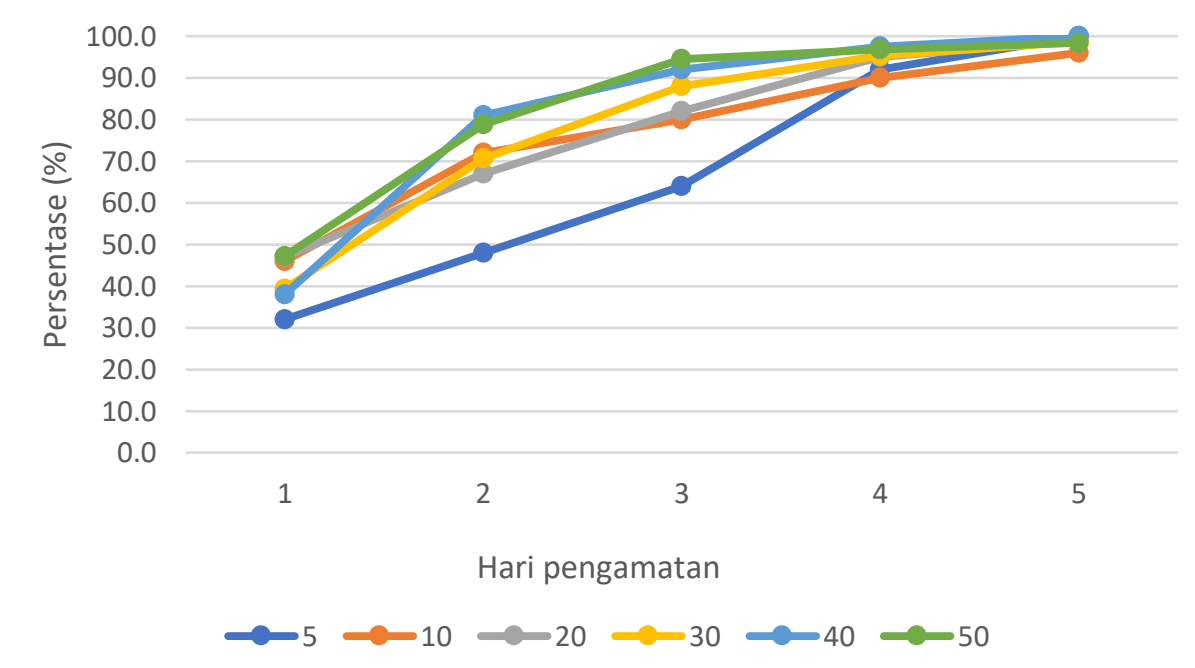

Gambar 3. Perkembangan daya predasi kumbang unta terhadap WBC pada kepadatan berbeda selama 5 hari pengamatan 
Nasral et al. Daya Predasi dan Tanggap Fungsional Kumbang Unta

Perkembangan berat tubuh kumbang unta (5 hari pengamatan)

Berat tubuh kumbang unta mengalami fluktuasi pada semua kepadatan selama 5 hari pengamatan dan tidak terlihat ada kecenderungan tertentu. Pada kepadatan 5, 40 dan 50 ekor WBC terjadi penambahan berat tubuh pada hari ke 2 pengamatan. Sementara pada kepadatan 10, 20 dan 30 mengalami penurunan dihari kedua pengamatan. Pada pengamatan hari ke 3 pengamatan, berat tubuh kumbang unta pada seluruh kepadatan mengalami kenaikan, hanya pada kepadatan 40 yang mengalami penurunan. Pada saat pengamatan hari ke 4 pengamatan, berat tubuh kumbang unta pada semua kepadatan mengalami penurunan. Sementara pada hari ke 5 pengamatan, kumbang unta pada kepadatan 5, 10, dan 30 mengalami kenaikan berat badan sedangkan pada kepadatan 20,40, dan 50 mengalami penurunan (Gambar 5).

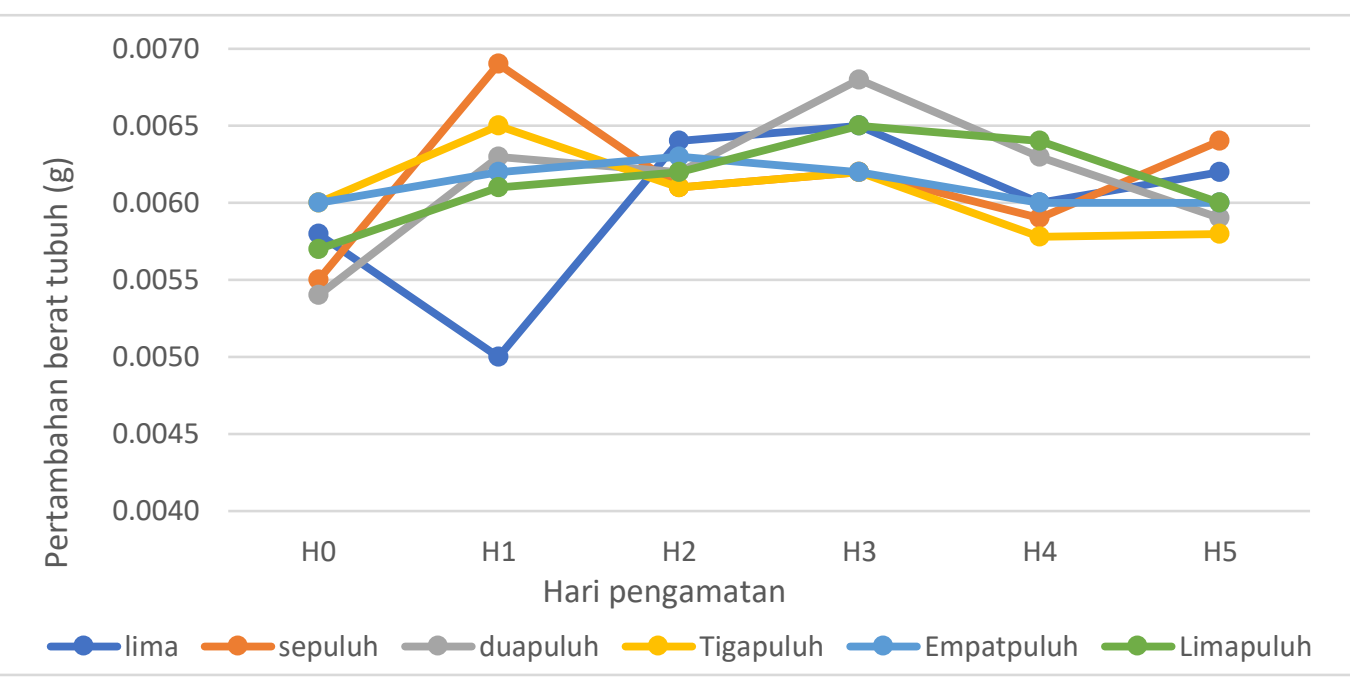

Gambar 4. Perkembangan berat tubuh kumbang unta dengan penyediaan WBC pada kepadatan berbeda selama 5 hari pengamatan

Tipe tanggap fungsional kumbang unta

Berdasarkan analisis regresi sederhana yang telah dilakukan didapatkan hasil bahwa tipe tanggap fungsional kumbang unta adalah tipe I (linear) dengan nilai $r=$
0,876 . Ini menunjukan bahwa daya predasi kumbang unta meningkat seiring dengan meningkatnya kepadatan mangsa dan menurun seiring menurunnya kepadatan mangsa (Tabel 4, Gambar 6).

Tabel 4. Tipe tanggap fungsional kumbang unta terhadap beberapa kepadatan WBC berdasarkan hasil analisis regresi dan nilai $r$

\begin{tabular}{llll}
\hline Tipe & Tipe regresi & Persamaan & Nilai $r$ \\
\hline I & Linear & $\mathbf{Y}=\mathbf{1 , 5 4 0}+\mathbf{0 , 0 6 6 x}$ & $\mathbf{0 , 8 6 7 ^ { * }}$ \\
II & Eksoponensial & $\mathrm{Y}=1,697 \times 0,022^{\mathrm{x}}$ & 0,863 \\
III & Logaritmik & $\mathrm{Y}=-0,643 \times \mathrm{x}^{1,034}$ & $\mathbf{0 , 8 4 2}$ \\
\hline
\end{tabular}

*Tipe tanggap fungsional kumbang unta ditentukan berdasarkan nilai $r$ tertinggi

\section{Perilaku pemangsaan}

Berdasarkan pengamatan yang dilakukan selama 5 hari. Saat pertama kali dimasukan ke dalam wadah uji, kumbang unta cenderung bergerak ke arah atas batang padi dan menghindari WBC yang ada disekitarnya. Kumbang unta cenderung diam dan sedikit sekali melakukan pergerakan pada siang hari. Kumbang unta baru beraktifitas ketika kondisi gelap atau malam hari (nokturnal). 


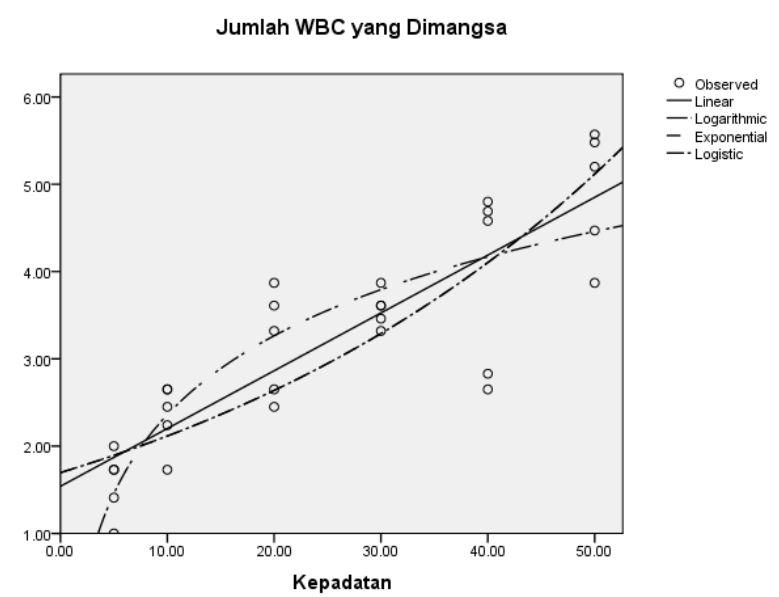

Gambar 5. Bentuk garis regresi dari daya predasi kumbang unta pada kepadatan WBC yang berbeda

Sebelum mencari mangsa, kumbang unta sangat aktif menggerakkan antenanya. Kumbang unta mencari mangsa dengan cara terbang ke segala arah denga cepat sehingga mangsanya terganggu dan terjatuh. Setelah terjatuh, kumbang unta menangkap mangsa menggunakan mulut serta langsung menangani saat itu juga ditempat dimana mangsa tersebut ditangkap. Kumbang unta memangsa WBC sedikit demi sedikit, dimulai dari bagian abdomen hingga menghabiskan seluruh bagian tubuh mangsanya, namun terkadang juga menyisakan bagian kepala dari WBC. Pada umumnya, kum-bang unta menuntaskan menangani satu mangsa hingga habis, setelah itu langsung mencari mangsa baru tanpa beristirahat terlebih dahulu.

Kumbang unta kurang baik dalam mengatur laju terbangnya. Selama pengujian berlangsung, dia terus terbang ke segala arah menuju ke atas sehingga menabrak bagian tutup wadah uji. Aktifitas seperti itu dilakukan terus menerus pada malam hari dan diduga sangat berpengaruh terhadap kebutuhan nutrisi dan berat tubuhnya.

\section{PEMBAHASAN}

Secara umum, kumbang unta berpotensi sebagai agens hayati WBC karena daya predasi meningkat seiring dengan meningkatnya kepadatan WBC. Sementara itu perbedaan kepadatan WBC tidak berpengaruh nyata terhadap persentase predasi dari kumbang unta (Tabel 1). Kumbang unta memiliki kecenderungan untuk menyisakan mangsa dan baru menghabiskannya setelah 5 hari pengamatan (Gambar 3). Berbeda dengan daya predasi, perbedaan kepadatan WBC cenderung tidak berpengaruh nyata terhadap pertambahan berat dari kumbang unta bahkan pada hari ke 5 mengalami penurunan berat tubuh. Selama lima hari pengamatan, pertambahan berat kumbang unta berfluktuasi dan cenderung menurun pada semua kepadatan (Gambar 4).

Predator pada dasarnya memiliki kecenderungan untuk meningkatkan jumlah mangsa yang dipredasi ketika jumlah mangsa ditambah. Berdasarkan hasil penelitian Syahrawati et al. (2015), kemampuan mempredasi Pardosa pseudoannulata meningkat seiring dengan meningkatnya kepadatan WBC. Pada kepadatan 5 ekor $P$. pseudoannulata dapat 
mempredasi 3,1 ekor WBC/hari dan pada kepadatan 20 mempredasi 15,2 ekor WBC/hari. Hermanda (2019) juga melaporkan bahwa daya predasi Phidippus sp pada kepadatan 10 ekor WBC adalah 9,0 ekor/hari dan pada kepadatan 50 ekor mempredasi 28,2 ekor/hari. Taulu (2001) mengemukakan jumlah mangsa yang dimangsa oleh predator akan bertambah dengan meningkatnya populasi mangsa yang tersedia. Daya predasi tertinggi berada pada kepadatan tertinggi dan akan menurun pada kepadatan mangsa rendah.

Daya predasi kumbang unta pada kepadatan 20 ekor nimfa WBC instar 2-3 adalah 9,4 ekor WBC/hari. Hal ini lebih tinggi dari hasil yang didapatkan oleh Karindah (2011) yang menyatakan bahwa kumbang unta dapat memangsa 4,36 ekor nimfa WBC instar 4-5 per hari. Perbedaan kemampuan memangsa ini diduga dikarenakan perbedaan instar WBC yang digunakan. Semakin tinggi instar yang digunakan maka ukuran tubuh WBC akan semakin besar. Omkar dan Perves (2004) menyatakan bahwa laju pemangsaan dan waktu pemangsaan dipengaruhi adanya variasi ukuran mangsa, tingkat kerakusan mangsa, faktor kekenyangan, tingkat kelaparan pemangsa, dan kecepatan bergerak mangsa. Sejalan dengan ini, Prasaja et al. (2014) juga melaporkan tentang daya predasi Chelisoches morio terhadap larva Brontispa longisima bahwa daya predasi $C$. morio lebih tinggi pada instar 1 dibandingkan instar 4.

Persentase predasi tertinggi ditemukan pada kepadatan 50 ekor WBC yakni sebesar $47,2 \%$ dan yang terendah ada pada kepadatan 5 ekor WBC yakni 32,0\% (Gambar 3). Perkembangan daya predasi kumbang unta diamati selama 5 hari. Pada hari ke 2 hingga hari ke 5 pengamatan, terjadi penurunan jumlah individu WBC yang dimangsa, ini disebabkan karena kurangnya mangsa yang tersedia untuk kumbang unta. Semakin sedikitnya mangsa membuat kumbang unta membutuhkan waktu yang lebih lama untuk mencari mangsanya. Susilo (2007) menyatakan predator akan menjadi semakin efisien pada populasi mangsa tertinggi, karena sebagian besar waktu digunakan hanya untuk menangkap mangsa. Ginting et al. (2017) juga menyatakan semakin sedikit mangsa yang tersedia, semakin lama waktu yang dibutuhkan untuk mencari mangsa, sebaliknya semakin banyak mangsa yang tersedia maka waktu yang dibutuhkan semakin sedikit.

Perkembangan berat tubuh kumbang unta selama 5 hari pengamatan mengalami fluktuasi. Hal ini dapat dipengaruhi oleh perbedaan kebutuhan, waktu beraktifitas dan perilaku memangsa. Salah satu indikator untuk memastikan kualitas predasi adalah penambahan berat tubuh. Syahrawati et al. (2015) menyatakan bahwa berat tubuh predator meningkat apabila daya predasi meningkat. Hal ini ternyata tidak berlaku terhadap kumbang unta, pertambahan berat tubuh kumbang unta cenderung berfluktuasi. Hal ini diduga karena kumbang unta banyak menggunakan energi untuk beraktifitas, dengan selalu terbang ke segala arah dalam mencari mangsa pada malam hari. Khodijah et al. (2012) menyatakan bahwa kumbang dari genus Carabidae mempunyai kemampuan jelajah dan kemampuan mencari mangsa yang tinggi. Kumbang Carabidae juga umumnya suka mempredasi serangga yang berukuran lebih besar dari dirinya. Sejalan dengan kemampuan jelajah dan mencari mangsa yang tinggi maka dibutuhkan energi yang lebih banyak. Sehingga pertambahan berat kumbang unta selama 5 hari pengamatan mengalami fluktuasi.

Tipe tanggap fungsional merupakan salah satu faktor penting untuk menentukan keefektifitasan suatu predator dalam hubungan suatu predator dengan mangsanya, karena kita dapat 
memperkirakan kemampuan predator tersebut dalam mengendalikan mangsanya. Tipe tanggap fungsional dari kumbang unta adalah tipe I (linear) dengan nilai $r=$ 0,867 . Hal ini menunjukan bahwa semakin tinggi kepadatan mangsa maka daya predasi dari kumbang unta juga meningkat, hanya konstan pada saat kumbang unta mengalami kejenuhan makan. Hal ini sesuai dengan hasil yang didapatkan oleh Effendi et al. (2016) bahwa tanggap fungsional tiga predator seperti Coccinela transversalis terhadap Menochilus sexmaculatus, Aphis gossypii dan Myzus persicae tergolong tipe I.

\section{KESIMPULAN}

Kumbang unta (Ophionea nigrofasciata) berpotensi dalam mengendalikan wereng batang coklat atau WBC (Nilaparvata lugens) ketika populasi sedang tinggi karena daya predasinya meningkat seiring dengan meningkatnya kepadatan WBC. Pemangsaan tertinggi terjadi pada kepadatan 50 ekor WBC yakni sebesar 23,6 (47,2\%) dan yang terendah pada kepadatan 5 ekor WBC yakni sebesar $1,6(32,0 \%)$. Perbedaan kepadatan WBC ternyata tidak mempengaruhi pertambahan berat tubuh kumbang unta bahkan cenderung menurun karena sangat aktif bergerak.

\section{DAFTAR PUSTAKA}

BPTPH Sumatera Barat. 2019. Luas serangan OPT padi dan pengendalianya tahun 2018 di Sumatera Barat.

Defaosandi A. 2010. Keefektifan beberapa Insektisida terhadap Nilaparvata lugens (Stal) (Hemiptera: Delpachidae) dan pengaruhnya terhadap musuh alami pada pertanaman padi di Karawang berdasarkan dua metode aplikasi insektisida. [Skripsi]. Institut Pertanian Bogor. Bogor.
Denny dan Mark. 2014. Buzz holling and the functional response. Bulletin of the Ecological Society of America 95(3): 200-203.

Effendi S, Yaherwandi dan N Nelly. 2016. Studi preferensi dan tanggap fungsional Menochilus sexmaculatus dan Coccinella transversalis pada beberapa mangsa yang berbeda. Prosiding Seminar Nasional Masyarakat Biodiversitas Indonesia 2(2): 125-131.

Ginting TY, D Bakti dan Marheni. 2017. Daya predasi dan respon fungsional Curinus coeruleus Mulsant (Coleoptera: Coccinelidae) terhadap Paracoccus marginatus Williams dan Granara De Willink (Hemiptera: Pseudococcidae) di rumah kaca. Jurnal Pertanian Tropik 4(3): 196-202.

Hermanda A. 2019. Daya pemangsaan Phidippus sp. terhadap Nilaparvata lugens Stal (Hemiptera: Delphacidae) pada kepadatan berbeda. [Skripsi]. Universitas Andalas. Padang.

Holling CS. 1959. Some characteristics of simple types of predation and parasitism. Canadian Entomologist 91: 395-398.

Karindah. 2011. Predation of five generalist predators on brown planthopper Nilaparvata lugens (Stal). Jurnal Entomologi Indonesia 8(2): 55-62.

Khodijah, S Herlinda, C Irsan, Y Pujiastuti, dan R Thalib. 2012. Artropoda predator penghuni ekosistem persawahan lebak dan pasang surut Sumatera Selatan. Jurnal Lahan Suboptimal 1(1): 57-63.

Liputan6.com. 2017. Wereng coklat mengamuk di lahan 1.000 hektare. https://www.liputan6.com/regiona I/read/3020180/wereng-cokelatmengamuk-di-lahan-1000-hektar. (Diakses, 29 Januari 2019). 
Najah SK. 2018. Kelmipahan wereng batang coklat Nilaparvata lugens (Stal) dan walang sangit Leptocorisa oratorius (Fabricius) serta predatornya pada tanaman padi varietas IR64. [Skripsi]. Institut Pertanian Bogor. Bogor.

Nelly N, Trizelia dan Q Syuhadah. 2012. Tanggap fungsional Menochilus sexmaculatus Fabricius (Coleoptera: Coccinellidae) terhadap Aphis gossypii (Glover) (Homoptera: Aphididae) pada umur tanaman cabai berbeda. Jurnal Entomologi Indonesia 9(1): 23-31

Omkar dan Pervez A. 2004. Predaceous coccinellids in India: Predator prey catalogue. Oriental Insects 38: 2761.

Prasaja GY, TH Ramadhana dan E Syahputra. 2014. Preferensi dan respon fungsional chelisoches morio Terhadap Larva Brontispa longissima di laboratorium Balai Proteksi Tanaman Perkebunan Pontianak. Jurnal Perkebunan dan Lahan Tropika 4(2): 30-38.

Putranto IR. 2016. Perkembangan populasi hama tanaman utama dan predatornya pada pertanaman padi sawah di situ Gede Bogor. [Skripsi]. Institut Pertanian Bogor. Bogor.

Shepard BM, AT Barrion dan JA Litsinger. 1987. Helpful Insect, spiders, and patoghens. International Rice Research Institute. Los Banos, Philipines.

Susilo FX. 2007. Pengendalian hayati: Dengan memberdayakan musuh alami. Graha Ilmu. Yogyakarta.

Syahrawati M, E Martono, NS Putra, dan BH Purwanto. 2015. Predation and competition of two predators (Pardosa pseudoanulata and Verania lineata) on diferent densities of Nilaparvata Lugens in laboratory. International Journal of
Science And Research (IJSR) 4(6): 615- 620.

Syahrawati M, OA Putra, R Rusli dan E Sulyanti. Population structure of brown planthopper (Nilaparvata lugens, Hemiptera: Delphacidae) and attack level in endemic area of Padang city, Indonesia. Asian Journal of Agriculture and Biology 7 (special issue): 271-276.

Taulu LA. 2001. Kompleks artropoda predator penghuni tajuk kedelai dan peranannya dengan perhatian utama pada Paederus fuscipes (Gurt.) (Coleoptera: Staphylinidae). [Disertasi]. Program Pascasarjana Institut Pertanian Bogor. Bogor.

Tauruslina E, Trizelia, Yaherwandi, dan $\mathrm{H}$ Hamid. 2015. Analisis keanekaragaman hayati musuh alami pada eksosistem padi sawah di daerah endemik dan non-endemik wereng batang cokelat Nilaparvata lugens di Sumatera Barat. Prosiding Seminar Masyarakat Biodiversitas Indonesia 1(3): 581-589. 